\begin{tabular}{|l|l|}
\hline Research Articles & Open Access \\
\hline
\end{tabular}

\title{
Analysis of Genetic Diversity in Thirteen Turfgrass Cultivars Cultivated at Golf Courses Using RAPD Markers
}

\author{
Min-Jeong Kim¹, Tae-Soo Kim², Chang-Ki Shim ${ }^{1 *}$, Yong-Ki Kim ${ }^{1}$ and Hyeong-Jin Jee ${ }^{1}$ \\ ${ }^{\prime}$ Organic Agriculture Division, National Academy of Agricultural Science, Rural Development Administration, \\ Suwon, Gyeonggi-do 441-707, Korea \\ ${ }^{2}$ Division of Applied Life Science Graduate School, Gyeongsang National University, Jinju, \\ Gyeongsangnam-do 660-701, Korea
}

\begin{abstract}
This study was carried our to examine the genetic relationship of 13 commercial turfgrass cultivars using Random Amplified Polymorphic DNA to provide genetic informations more efficient golf course management. Analysis of 56 random hexamer primers generated 13 to 54 polymorphic bands among the 13 cultivars with an average of 30.7 bands per primer. The results of cluster analysis based on RAPDs revealed that three major variety groups: Group I - 'Shadow II', 'Aurora Gold', 'Little Bighorn Blue', 'PennA-1', and 'PennA-4'; Group II - 'Midnight II', 'Prosperity', 'Moon light SLT', 'Bright star SLT', and 'Silver dollar'; and Group III - 'Olympic Gold', 'Silver Star', and 'Tar Heel II'. The genetic similarity coefficients among 13 turfgrass cultivars ranged from 0.039 to 1.0 with highest coefficient in Group III. Studies on morphological characters and the effective molecular markers such as sequence characterized amplified regions are further needed to identify relationships and genetic diversities within species and among species.
\end{abstract}

Key words: Cultivar, Genetic similarity, Random Amplified Polymorphic DNA, Turfgrass

\section{Introduction}

Turfgrasses have low growing habit, prostrating tendency, high shoot density, and coarse-to-fine leaf texture (Beard, 1973; Alderson and Sharp, 1994). Most turfgrasses have been established, adapted, and persisted in areas distant from their initial origin (Beard, 1973). All cultivated turfgrass have been improved by selection and breeding from collected germpla and distributed mainly during the first half of 20th century (Hitchcock, 1950).

Warm-season turfgrasses have been used extensively as lawn grass or on athletic fields in subtropical and transitional zones because of their high stress tolerance such as drought and shade and excellent disease resistance (Beard, 1973; Cockerham et al., 1994; Kim et al., 1987). Morphological classification of turfgrass cultivars has mostly been conducted with multi-genic and quantitative traits, leaf blade color, texture, shape, length, blade angle, and growth habit (Rafalski and Tingery, 1993). The application of DNA technology in agricultural research has progressed rapidly over the last twenty years, especially in cultivar identification (Nyborm, 1990).

\footnotetext{
*Corresponding author; Chang-Ki Shim

Tel: +82-31-290-0545, Fax: +82-31-290-0507

E-mail: ckshim@korea.kr

Received : July 31, 2012, Revised : August 14, 2012, Accepted : September 04, 2012
}

Among the turfgrass genera, common bermudagrass (Cynodon dactylon L. Pers.), tall fescue (Festuca arundinacea Schreb.), and perennial ryegrass (Lolium perenne L.) are perennial species wildly used in landscaping (Thorogood, 2003). Common bermudagrass is a member of the Poaceae family, Eragrostoideae sub-family, and Chlorideae tribe. It is a native of eastern Africa (Beard, 1973).

Recently, a wide range of molecular markers have been available. The techniques applied to turfgrass study include those that are based in nucleic acid hybridization, such as RFLP analysis (Botstein et al., 1980), those that selectively amplify highly informative genomic regions, such as SSR analysis (Litt and Luty, 1989; Weber and May, 1989), and those that scan nucleic acids by amplification, such as RAPD (Williams et al., 1990), DAF (Caetano-Anolles et al., 1991), and derived methods such as ASAP (Caetano-Anolles and Gresshoff, 1996), and RAFLP analysis (Sweeney and Danneberger, 1996).

PCR based methods require lower amounts of genomic DNA, are relatively low cost, and can be developed rapidly. RAPD marker can be used in the systematic study of wild plants and new crops. A major advantage of RAPD markers over some other DNA based markers is that they require no prior sequence information, and no prior knowledge about any particular gene in a target taxon (Golembiewski et al., 1997; Palumbi, 1996; Al-Humaid and Motawei, 2004)

Continuous expansion will be hampered by turfgrass 
Table 1. List of turfgrass used in the study.

\begin{tabular}{lll}
\hline \hline Cultivar & Common name & Scientific name \\
\hline Shadow II & Chewing's fescue & Festuca rubra L. spp. Commutata Gaud. \\
PennA-1 & Creeping bentgrass & Agrostis palustris Huds. \\
PennA-4 & Creeping bentgrass & A. palustris Huds. \\
Aurora Gold & Hard fescue & F. longifolia Thuill. \\
Little Big Horn Blue & Hard fescue & F. longifolia Thuill. \\
Midnight II & Kentucky bluegrass & Poa pratensis L. \\
Moonlight SLT & Kentucky bluegrass & P. pratensis L. \\
Prosperity & Kentucky bluegrass & P. pratensis L. \\
Bright Star SLT & Perennial ryegrass & Lolium perenne L. \\
Silver Dollar & Perennial ryegrass & L. perenne L. \\
Olympic Gold Turf-Type & Tall fescue & F. arundinacea Schrub.(syn. F. elatior, L. arundinaceum) \\
Silver Star Turf-Type & Tall fescue & F. arundinacea Schrub.(syn. F. elatior, L. arundinaceum) \\
Tar Heel II Turf-Type & Tall fescue & F. arundinacea Schrub.(syn. F. elatior, L. arundinaceum) \\
\hline
\end{tabular}

susceptibility to disease and pest and its ability to adapt to the environment because of low genetic diversity of turfgrass species in Korea (Warnke et al., 1997; Choi and Yang, 2006; Kubik et al., 2009). Golf course managers are now searching for alternative control of the disease (Im and Kim, 1999; Chang et al., 2009; Chang et al., 2010).

This study analyzed the genetic diversity of the commercial turfgrass cultivars used as mono and hybridization components on golf courses in Korea to provide basic information on developing turfgrass cultivars.

\section{Materials and Methods}

\section{Plant materials}

A total of 13 commercial turfgrass cultivars from six species were used in the study: one chewing's fescue (Festuca rubra L. spp. commutata Gaud., 'Shadow II'); two creeping bentgrass (Agrostis palustris Huds., 'PennA-1' and 'PennA-4'); two hard fescue (F. longifolia Thuill., 'Aurora Gold' and 'Little Big Horn Blue'); three Kentucky bluegrass (Poa pratensis L., F. longifolia Thuill., 'Midnight II', 'Moonlight SLT', and 'Prosperity'); two perennial ryegrass (Lolium perenne L., 'Bright Star SLT' and 'Silver Dollar'); and three tall fescue ( $F$. arundinacea Schreb., 'Olympic Gold', 'Silver Star', and 'Tar Heel II') (Table 1). These cultivars were planted and maintained in the greenhouses for two months.

\section{DNA extraction}

DNA was extracted using modified Cetyltrimethyl ammonium bromide (CTAB) method (Doyle and Doyle, 1990). Genomic DNA was extracted from about $0.2 \mathrm{~g}$ of individual leaf tissue sample of each of the 13 cultivars. Each leaf sample was powdered finely with liquid nitrogen. Genomic DNA was extracted in $750 \mu \mathrm{L}$ of pre-warmed $\left(65^{\circ} \mathrm{C}\right) 1 \%$ CTAB buffer consisting of $1.5 \mathrm{M} \mathrm{NaCl}, 100 \mathrm{mM}$ Tris-HCl (pH 8.0), $20 \mathrm{mM}$ EDTA, and 1\% CTAB. The homogenate was incubated for $30 \mathrm{~min}$ at $60^{\circ} \mathrm{C}$ and saturated with equal volume of chloroform/isoamyl alcohol (24:1). After being vortexed gently for three minutes the mixtures were centrifuged at $12,000 \mathrm{rpm}$ for $10 \mathrm{~min}$ at $4^{\circ} \mathrm{C}$. The supernatant was transferred to new tubes and cold isopropanol was added to 2/3 volume of supernatant. After 30 min on ice, genomic DNA was precipitated by centrifugation at $12,000 \mathrm{rpm}$ for $10 \mathrm{~min}$ at $4^{\circ} \mathrm{C}$. The pellets were washed with $70 \%$ ethanol and dissolved in TE buffer $(\mathrm{pH} 7.5)$. The quality of DNA was examined on a $1 \%$ agarose gel stained with ethidium bromide. The DNA concentration was quantified by Nano Drop system (Thermo, Wilmington, U.S.A.), diluted to working concentration of $10 \mathrm{ng} / \mu \mathrm{L}$, and stored at $4 \mathrm{oC}$.

\section{PCR conditions and genotyping of the RAPD markers}

The PCR analysis followed the procedures by Bioneer PCR premix kit (Bioneer Co. Ltd., Korea). A total of 56 random hexamer primers were selected for assessing RAPD analysis of 13 turfgrass cultivars (Table 2). Polymorphic DNA bands were amplified with Bioneer premix kit (Bioneer Co. Ltd., Korea) in a reaction volume of $20 \mathrm{uL}$ containing $16 \mathrm{uL}$ of deionized distilled water, $2.0 \mathrm{uL}$ of random primer, and $2 \mathrm{uL}$ of template DNA (20 ng).

Amplifications were carried out in a MyGenie96 Thermal cycler (Bioneer Co. Ltd., Korea). The programmed DNA template was initially denatured at $94^{\circ} \mathrm{C}$ for $5 \mathrm{~min}$, followed by 30 cycles of PCR amplifications with a 30 -sec denaturation at $94^{\circ} \mathrm{C}, 30$-sec primer annealing from 42 to $60^{\circ} \mathrm{C}$, and a 
Table 2. List and information of random primers in this study.

\begin{tabular}{cc|cc|cc|cc}
\hline \hline Primer & Sequence $\left(5^{\prime} \rightarrow 3\right)$ & Primer & Sequence $\left(5^{\prime} \rightarrow 3\right)$ & Primer & Sequence $\left(5^{\prime} \rightarrow 3\right)$ & Primer & Sequence $\left(5^{\prime} \rightarrow 3\right)$ \\
\hline P127 & ATCTGGCAGC & P153 & GAGTCACGAG & P214 & CATGTGCTTG & P247 & TACCGACGGA \\
P128 & GCATATTCCG & P154 & TCCATGCCGT & P217 & ACAGGTAGAC & P250 & CGACAGTCCC \\
P129 & GCGGTATAGT & P156 & GCCTGGTTGC & P218 & CTCAGCCCAG & P251 & CTTGACGGGG \\
P130 & GGTTATCCTC & P159 & GAGCCCGTAG & P219 & GTGACCTCAG & P254 & CGCCCCATT \\
P131 & GAAACAGCGT & P160 & CGATTCAGAG & P225 & CGACTCACAG & P256 & TGCAGTCGAA \\
P133 & GGAAACCTCT & P167 & CCAATTCACG & P229 & CCACCCAGAG & P260 & TCTCAGCTAC \\
P135 & AAGCTGCGAG & P171 & TGACCCCTCC & P231 & AGGGAGTTCC & P265 & CAGCTGTTCA \\
P139 & CCCAATCTTC & P179 & TCACTGTACG & P232 & CGGTGACATC & P266 & CCACTCACCG \\
P141 & ATCCTGTTCG & P182 & GTTCTCGTGT & P237 & CGACCAGAGC & P268 & AGGCCGCTTA \\
P144 & AGAGGGTTCT & P183 & CGTGATTGCT & P239 & CTGAAGCGGA & P269 & CCAGTCGCC \\
P146 & ATGTGTTGCG & P185 & GTGTCTTCAC & P240 & ATGTTCCAGG & P273 & AATGTCGCCA \\
P147 & GTGCGTCCTC & P189 & TGCTAGCCTC & P242 & CACTCTTTGC & P274 & GTTCCCGAGT \\
P150 & GAAGGCTCTG & P197 & TCCCCGTTCC & P244 & CAGCCAACCG & & \\
P151 & GCTGTAGTGT & P211 & GAAGCGCGAT & P246 & TATGGTCCGG & & \\
\hline
\end{tabular}

1-min primer extension at $72^{\circ} \mathrm{C}$ allowing for completion of primer extension, with final extension at $72^{\circ} \mathrm{C}$ for $10 \mathrm{~min}$. Initially, $5 \mu \mathrm{L}$ of the amplified product was electrophoretically resolved in a $1.5 \%$ agarose gel in $0.5 \mathrm{X}$ Tris-acetate-EDTA (TAE) buffer ( $\mathrm{pH} 8.0$ ) and visualized under UV light after staining with $0.1 \mathrm{ug} / \mathrm{ml}$ of ethidium bromide (Et-Br). The polymorphic bands were scored " 1 " if present and " 0 " if absent. A similarity coefficient matrix was also formed. This matrix was analyzed by the "Power Marker" (http://statgen. ncsu.edu/powermarker/) software to construct a dendrogram and principal coordinate analysis. Using this similarity coefficient matrix, genetic distance was analyzed by a UPGMA method.

\section{Data analysis}

The clear bands from the gel images were scored manually, either as present, " 1 " or absent, " 0 " and a similarity coefficient matrix was formed. The results were confirmed with NTSYS-pc (Version 2.0, Numerical Taxonomy and Multivariate Analysis System) software. Similarity matrix was calculated using SIMQUAL. Sequential, agglomerative, hierarchical, and nested clustering was carried out with unweighted pairgroup method and arithmetic average (UPGMA) method. A simple matching coefficient was used to calculate the similarity coefficient matrix in NTSYS-pc.

\section{Results and Discussion}

Using RAPD analysis, 13 - 54 polymorphic bands were amplified and an average of 30.7 bands per primer generated. Only two primers, P128 and P130 which exhibited 100\% polymorphic alleles, amplified the genetically varied bands,

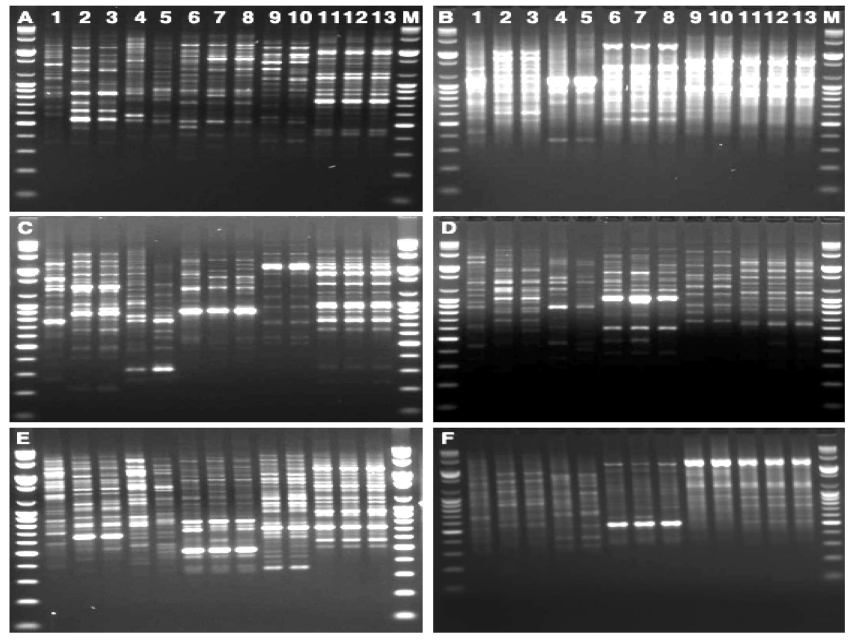

Fig. 1. Polymorphism patterns with random primers P127 (A), P128 (B), P129 (C), P130 (D), P131 (E), and P133 (F) to identify genetic differences for 13 turfgrass cultivars. $M$ lane: Molecular marker (100 bp of ladder DNA plus); lane 1: Shadow II; lane 2: 'PennA-1'; lane 3: 'PennA-4'; lane 4: 'Aurora Gold'; lane 5: 'Little Big Horn Blue'; lane 6: 'Midnight II'; lane 7: 'Moonlight SLT'; lane 8: 'Prosperity'; lane 9: 'Bright Star SLT'; lane 10: 'Silver Dollar'; lane 11: 'Olympic Gold'; lane 12: 'Silver Star' and lane 13: 'Tar Heel II'.

while 16 primers formed a single band (Fig. 1 and Table 3). A dendrogram analysis showed that 13 turfgrass cultivars were divided into three major groups, Group I, Group II, and Group III; Group I included five cultivars, Shadow II, 'Aurora Gold', 'Little Bighorn Blue', 'Penn A-1', and 'Penn A-4'. Also, Group II included five cultivars, 'Midnight II', 
Table 3. Number of polymorphic bands amplified from 13 turfgrass cultivars with each random primer.

\begin{tabular}{|c|c|c|c|c|c|c|c|}
\hline $\begin{array}{l}\text { Primer } \\
\text { No. }\end{array}$ & $\begin{array}{c}\mathrm{GC} \text { content } \\
(\%)\end{array}$ & $\begin{array}{l}\text { No. of total } \\
\text { bands }\end{array}$ & $\begin{array}{c}\text { No. of single } \\
\text { bands }\end{array}$ & $\begin{array}{l}\text { Primer } \\
\text { No. }\end{array}$ & $\begin{array}{c}\text { GC content } \\
(\%)\end{array}$ & $\begin{array}{c}\text { No. of total } \\
\text { bands }\end{array}$ & $\begin{array}{c}\text { No. of single } \\
\text { bands }\end{array}$ \\
\hline P127 & 60 & 34 & 2 & P211 & 60 & 32 & 3 \\
\hline P128 & 50 & 26 & 0 & P214 & 60 & 19 & 1 \\
\hline P129 & 50 & 44 & 5 & $\mathrm{P} 217$ & 50 & 42 & 9 \\
\hline P130 & 50 & 36 & 2 & $\mathrm{P} 218$ & 70 & 24 & 4 \\
\hline P131 & 50 & 52 & 8 & P219 & 60 & 35 & 3 \\
\hline P133 & 50 & 20 & 0 & P225 & 60 & 51 & 14 \\
\hline P135 & 60 & 23 & 2 & P229 & 70 & 28 & 8 \\
\hline P139 & 50 & 32 & 4 & P231 & 70 & 25 & 3 \\
\hline P141 & 50 & 44 & 6 & P232 & 60 & 15 & 1 \\
\hline P144 & 50 & 26 & 4 & P237 & 70 & 19 & 4 \\
\hline P146 & 50 & 25 & 4 & P239 & 60 & 20 & 3 \\
\hline P147 & 70 & 26 & 1 & $\mathrm{P} 240$ & 50 & 30 & 2 \\
\hline $\mathrm{P} 150$ & 60 & 26 & 6 & P242 & 50 & 36 & 9 \\
\hline $\mathrm{P} 151$ & 50 & 43 & 10 & $\mathrm{P} 244$ & 70 & 25 & 5 \\
\hline P153 & 60 & 13 & 2 & P246 & 60 & 39 & 6 \\
\hline P154 & 60 & 18 & 1 & P247 & 60 & 43 & 9 \\
\hline P156 & 70 & 20 & 2 & $\mathrm{P} 250$ & 70 & 26 & 4 \\
\hline P159 & 70 & 54 & 13 & $\mathrm{P} 251$ & 70 & 22 & 3 \\
\hline P160 & 50 & 23 & 5 & P254 & 70 & 48 & 7 \\
\hline P167 & 50 & 44 & 7 & $\mathrm{P} 256$ & 50 & 29 & 4 \\
\hline P171 & 70 & 32 & 6 & $\mathrm{P} 260$ & 50 & 37 & 7 \\
\hline P179 & 50 & 40 & 9 & P265 & 50 & 36 & 6 \\
\hline P182 & 50 & 45 & 5 & P266 & 70 & 32 & 5 \\
\hline P183 & 50 & 41 & 8 & P268 & 60 & 40 & 8 \\
\hline P185 & 50 & 24 & 5 & P269 & 70 & 29 & 4 \\
\hline P189 & 60 & 32 & 4 & P273 & 50 & 27 & 5 \\
\hline P197 & 70 & 30 & 3 & P274 & 60 & 37 & 10 \\
\hline
\end{tabular}

'Prosperity', 'Moon light SLT', 'Bright star SLT', and 'Silver dollar'. Group III included three cultivars, 'Olympic Gold', 'Silver Star', and 'Tar Heel II'. This is confirmed by their genetic distance (Fig. 2).

The turfgrass cultivar classification is difficult because it has mostly relied on morphological characteristics that are multigenic, quantitative, and easily modified by environmental factors. Individual performance of cultivars and varieties within each classification may be vary widely and require comparative observation (Rafalski and Tingery, 1993).

The genetic similarity of Group I, Group II, and Group III were $0.039 \sim 0.966,0.827 \sim 0.977$, and 1.0, respectively. Group III had the highest genetic similarity (Fig. 3 and Table 4).

Most of the cultivated pasture and turfgrasses originated from Eurasia (Hartley and Williams 1956). They were key elements in the migration of livestock agriculture throughout
Eurasia. Numerous perennial grasses have developed tolerance to saline soils in coastal salt marshes and beaches to rocky, alpine environments (Wu, 1981; Acharya et al., 1992).

Characterization of each accession of these species is critically important to be able to use turfgrass genetic breeding materials. Molecular markers are a powerful, reliable, and cost-effective tool for evaluating genetic diversity and can provide important insights for breeding. It is also necessary to identify the relationships and the differences of genetic diversity within species. Morphological studies need to be carried and the effective markers such as SCARs need further study.

This study revealed the genetic diversity of 13 turfgrass cultivars commercially used on the golf courses in Korea. Turfgrass cultivars most widely used on the golf courses in Korea were effectively classified through morphological 

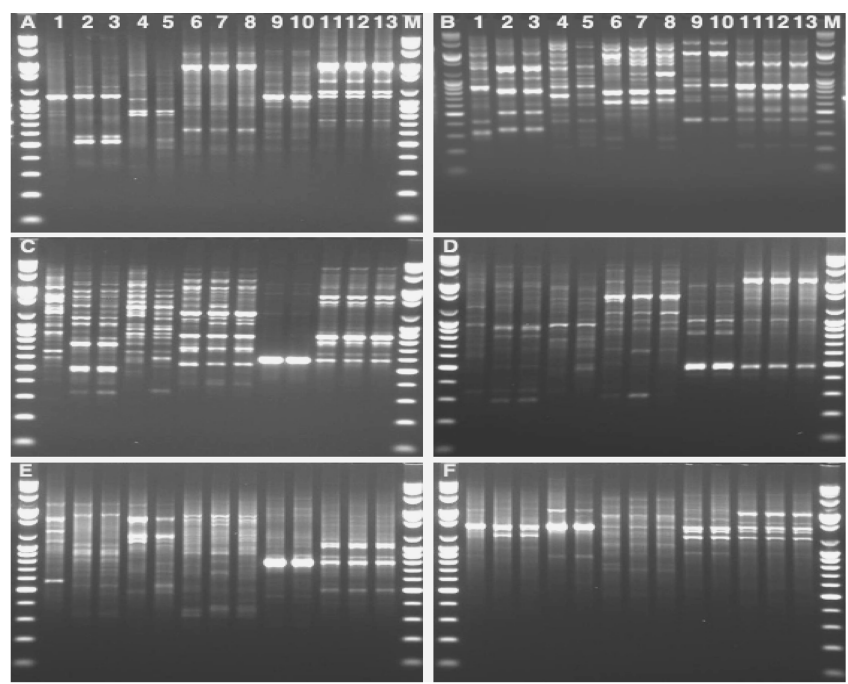

Fig. 2. $P C R$ band patterns generated by random primers $P 135$ (A), P139 (B), P141 (C),P144 (D), P146 (E), and P 147 (F) to identify genetic differences for 13 turfgrass cultivars. $M$ lane: Molecular marker (100 bp of ladder DNA plus); lane 1: Shadow II; lane 2: 'PennA-1'; lane 3: 'PennA-4'; lane 4: 'Aurora Gold'; lane 5: 'Little Big Horn Blue'; lane 6: 'Midnight II'; lane 7: 'Moonlight SLT'; lane 8: 'Prosperity'; lane 9: 'Bright Star SLT'; lane 10: 'Silver Dollar'; lane 11: 'Olympic Gold'; lane 12: 'Silver Star'and lane 13: 'Tar Heel II.

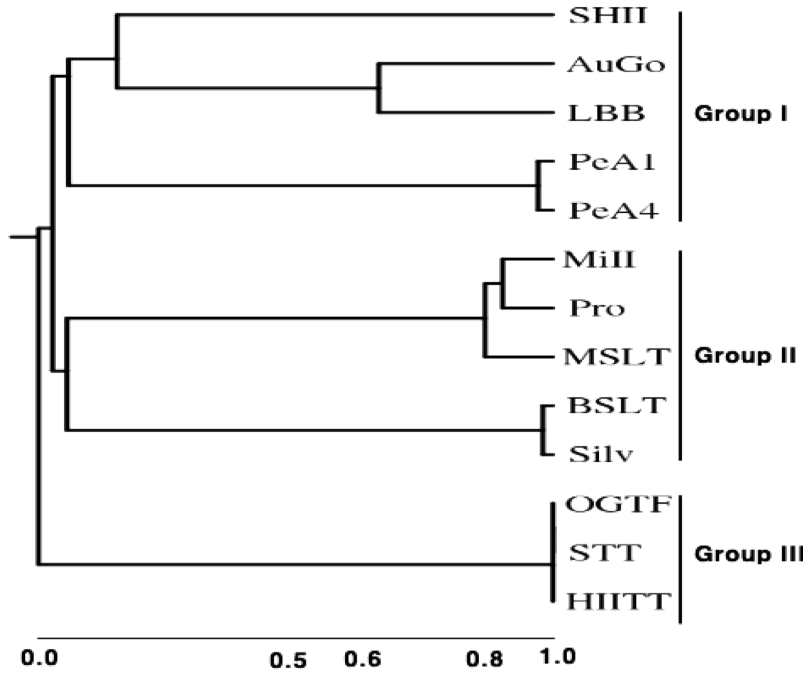

Fig. 3. The genetic dendrogram of 13 turfgrass cultivars was constructed from similarity coefficients and showing the clustering of the unweighted pair group average linkage of Pearson coefficients. SHII: 'Shadow II'; PeA1: 'PennA-1'; PeA4: 'PennA-4'; AuGo: 'Aurora Gold'; LBB: 'Little Big Horn Blue; MiII: 'Midnight II'; MSLT: 'Moonlight SLT'; Pro: 'Prosperity'; BSLT: 'Bright Star SLT'; Silv: 'Silver Dollar'; OGTF: 'Olympic Gold' ; STT: 'Silver Star' and HIITT: 'Tar Heel II'.

Table 4. The genetic similarity matrix among 13 turfgrass cultivars used on golf courses in Korea based on Pearson coefficient (r).

\begin{tabular}{|c|c|c|c|c|c|c|c|c|c|c|c|c|c|}
\hline & SHII $^{\mathrm{x})}$ & PeAl & $\mathrm{PeA} 4$ & AuGo & LBB & MilI & MSLT & Pro & BSLT & Silv & OGTF & STT & HIITT \\
\hline SHII & 1 & -0.087 & -0.087 & 0.039 & -0.011 & -0.048 & -0.071 & -0.077 & -0.107 & -0.102 & -0.021 & -0.021 & -0.021 \\
\hline PeA1 & & 1 & 0.966 & -0.076 & -0.134 & -0.126 & -0.126 & -0.098 & -0.188 & -0.181 & -0.236 & -0.236 & -0.236 \\
\hline PeA4 & & & 1 & -0.076 & -0.134 & -0.126 & -0.108 & -0.098 & -0.188 & -0.181 & -0.253 & -0.253 & -0.253 \\
\hline AuGo & & & & 1 & 0.606 & -0.157 & -0.157 & -0.183 & -0.154 & -0.148 & -0.195 & -0.195 & -0.195 \\
\hline LBB & & & & & 1 & -0.134 & -0.113 & -0.160 & -0.14 & -0.134 & -0.151 & -0.151 & -0.151 \\
\hline MiII & & & & & & 1 & 0.827 & 0.886 & -0.089 & -0.102 & -0.173 & -0.173 & -0.173 \\
\hline MSLT & & & & & & & 1 & 0.867 & -0.110 & -0.124 & -0.173 & -0.173 & -0.173 \\
\hline Pro & & & & & & & & 1 & -0.054 & -0.087 & -0.161 & -0.161 & -0.161 \\
\hline BSLT & & & & & & & & & 1 & 0.977 & -0.147 & -0.147 & -0.147 \\
\hline Silv & & & & & & & & & & 1 & -0.140 & -0.140 & -0.140 \\
\hline OGTF & & & & & & & & & & & 1 & 1 & 1 \\
\hline STT & & & & & & & & & & & & 1 & 1 \\
\hline HIITT & & & & & & & & & & & & & 1 \\
\hline
\end{tabular}

×SHII: 'Shadow II'; PeA1: 'PennA-1'; PeA4: 'PennA-4'; AuGo: ‘Aurora Gold'; LBB: 'Little Big Horn Blue; MilI: 'Midnight II'; MSLT: 'Moonlight SLT'; Pro: Prosperity'; BSLT: 'Bright Star SLT'; Silv: 'Silver Dollar'; OGTF: 'Olympic Gold' ; STT: 'Silver Star' and HIITT: 'Tar Heel II'.

characterization. Their genetic similarity was analyzed based on RAPD data. These results can be providing basic information on identifying exported $t$ turfgrass cultivars in the markets.

\section{Acknowledgments}

This research was supported by a grant program (PJ907129 022012) funded by Rural Development Administration 
(RDA), Republic of Korea in 2012.

\section{References}

Alderson, J. and Sharp, W.C. 1994. Grass varieties in United States. USDA-SCS Agriculture Handbook. 170. U.S. Gov. Print. Office, Washington, DC.

Al-Humaid, A. and Motawei, M.I. 2004. Molecular characterization of some turfgrass cultivars using randomly amplified polymorphic DNA (RAPD) markers. J. Food Agri. \& Envi. 2:376380.

Acharya, S.N., Darroch, B.A., Hermesh, R. and Woosaree, J. 1992. Salt stress tolerance in native alberta populations of slender wheatgrass and alpine bluegrass. Can. J. Plant Sci. 72:785-792.

Beard, J.B. 1973. Turfgrass: Science and Culture. Prentice-Hall, Engle-wood Cliffs, NJ. U.S.A.

Bostein, D., White, R.L., Skolnick, M. and Davis, R.W. 1980. Construction of a genetic linkage map in man using restriction fragment length polymorphisms. Am. J. Hum. Genet. 32:314-331.

Caetano-Anollés, G. and Gresshoff, P.M. 1996. Generation of sequence signatures from DNA amplification fingerprints with mini-hairpin and microsatellite primers. Biotechniques 20: 1044-1056.

Caetano-Anollés, G., Bassam, B.J. and Gresshoff, P.M. 1991. DNA amplification fingerprinting using very shot arbitrary primers. Nature Biotech. 9:553-557.

Chang, S.W., Chang, T.H., Yang, G.M., Choi, J.S. and Rho, Y.T. 2010. Resistance evaluation of several turfgrass species and graminious crop species against Rhizoctonia cerealis and Typhula incarnate under controlled conditions. Korean Turfgrass Sci. 24:9-15. (In Korean)

Chang, S.W., Chang, T.H., Choi, B.J., Song, J.H., Park, K.S. and Rho, Y.T. 2009. Antagonistic effects of Pseudomonas spp. Against turfgrass pathogenic soil fungi. Korean Turfgrass Sci. 23:209218.

Choi, J.S. and Yang, G.M. 2006. Development of new cultivar 'Millock' in Zoysiagrass. Korean Turfgrass Sci. 20:1-10. (In Korean)

Cockerham, S.T., Gibeault, V.A. and Borgonovo, M. 1994. Traffic effects on turfgrasses under restricted light. California Turfgrass Culture 44:1-3.

Doyle, J.J. and Doyle, J.L. 1990. Isolation of plant DNA from fresh tissue. Focus 12:13-15.

Golembiewski, R.C., Danneberger, T.K. and Sweeney, P.M. 1997. Potential of RAPD markers for use in the identification of creeping bentagrass cultivars. Crop Sci. 37:212-214.

Hartley, W. and Williams, R.J. 1956. Centres of distribution of cultivated pasture grasses and their significance for plant introduction. pp. 190-199. In: Proc. $7^{\text {th }}$ Int. Grassland Conf., Palmerston
North, N.Z.

Hitchcock, A.S. 1950. Manual of the grasses of the United States. USDA Misc. Publ. No. 200. U.S. Govt. Print., Washington, D.C.

Im, S.H. and Kim, D.H. 1999. Selection of resistant lines against large patch disease in Zoysiagrass. Pp. 9-10. In: Proceeding of Korean Turfgrass Soc. 12.

Kim, K.S., Sifers, S.I. and Beard, J.B. 1987. Comparative drought resistances among major warm-season turfgrass species and cultivars. Texas Turfgr. Res. Consolidated Prog. Rep. PR4521:28-30. Texas Agric. Exp. Stn., Texas A\&M Univ., College Station, TX.

Kubik, C., Honig, J., William, A.M. and Stacy, A.B. 2009. Genetic diversity of creeping bentagrass cultivars using SSR markers. Int. Turfgrass Soc. Res. J. 11:533-547.

Litt, M. and Luty, J.A. 1989. A hypervariable microsatellite revealed by in vitro amplification of a dinucleotide repeat within the cardiac muscle actin gene. Am. J. Hum. Genet. 44:397-401.

Nyborm, H. 1990. Application of DNA fingerprinting in plant breeding. Proc. Intern. DNA Fingerprinting Symposium. Bern, Switzerland. pp. 32-45.

Palumbi, S.R. 1996. Nucleic acid II: The polymerase chain reaction, pp. 205-247. In: D. M. Hillis, C. Mortiz, and B. K. Mable (Eds). Molecular systematic. Sinauer Assoc., Sunderlnd, Mass.

Rafalski, J.A. and Tingery, S.V. 1993. Genetic diagnostics in plant breeding: RAPDs, microsatellites and machines. Trends Gen. 9:275-280.

Sweeney, P.M. and Danneberger, T.K. 1996. Restriction digestion of arbitrary amplification fragments of annual bluegrass. Crop Sci. 36:1301-1303.

Thorogood, D. 2003. Chapter 7. Perennial Rygrass (Lolium perenne L.). In: Turfgrass Biology, Genetics, and Breeding. M. D. Casler and R. D. Duncan (Eds). John Wiley \& Sons, Inc. Hoboken, N.J. pp 75-105.

Warnke, S.E., Douches, D.S. and Branham, B.E. 1997. Relationships among creeping bentagrass cultivars based on isozyme polymorphism. Crop Sci. 37:203-207.

Weber, J.L. and May, P.E. 1989. Abundant class of human DNA polymorphisms which can be typed using the polymerase chain reaction. Am. J. Hum. Genet. 44:388-396.

Williams, J.G.K., Kubelik, A.R., Livak, K.J., Rafalski, J.A. and Tingery, S.V. 1990. DNA polymorphisms amplified by arbitrary primers are useful as genetic markers. Nucleic Acids Res. 18:6531-6535.

$\mathrm{Wu}, \mathrm{L} .1981$. The potential for evolution of salinity tolerance in Agrostis stolonifera L. and Agrostis tenuis Sibth. New Phytol. 89:471-486. 


\title{
RAPD 마커를 이용한 국내골프장의 잔디 13 품종의 유전적 다양성 분석
}

\author{
김민정 ${ }^{1} \cdot$ 김태수 $^{2} \cdot$ 심창기 $^{1 *} \cdot$ 김용기 ${ }^{1} \cdot$ 지형진 $^{1}$ \\ ${ }^{1}$ 농촌진흥청 국립농업과학원 유기농업과, ${ }^{2}$ 경상대학교 응용생명과학대학원
}

요 약: 본 연구는 무작위 분자마커(RAPD)를 이용한 우리나라 골프장에서 이용되고 있는 잔디 13 개 잔디품종의 유전적 다형성을 조사하여 보다 효과적인 골프장 관리를 위한 유전적 정보를 제공하고자 조사하였다. 본 연구에 서 사용한 54개의 random hexamer primer를 이용하여 RAPD분석을 실시한 결과 13 54개의 다형성 밴드를 형성 하였으며 primer당 평균 30.7 개의 다형성 밴드를 확인할 수 있었다. RAPD분석 결과 13 개의 잔디품종은 크게 3 개 의 그룹으로 나눌 수 있었다. Group I은 Shadow II, Aurora Gold, Little Big Horn Blue, PennA-1, PennA-4, Group II는 Midnight II, Prosperity, Moonlight SLT, Bright Star SLT, Silver Dollar, Group III은 Olympic Gold Turf-Type, Silver Star Turf-Type, Tar Heel II Turf-Type을 포함하였다. 13개 잔디 품종의 유전적 근연 정도는 0.039 1.0으로 나 타났으며, Group III이 유전적 근연 정도가 가장 높게 나타났다. 이상의 결과를 통해 향후, 잔디 종 또는 이종간의 유전적 다양성의 상호관계나 차이점을 규명하기 위해서는 형태적인 특성과 SCARs 마커와 같은 특이적인 분자마 커에 대한 연구가 추가적으로 필요할 것으로 사료된다.

주요어: 잔디, 품종, 유전적 유연관계, RAPD 